\title{
Embracement in gynecological nursing consultation: women's perceptions of the Family Health Strategy
}

\author{
Acolhimento na consulta ginecológica de enfermagem: percepções de mulheres da \\ Estratégia Saúde da Família
}

Maria Gleiciane Lima Rocha ${ }^{1}$, Andrea Gomes Linard ${ }^{1}$, Lydia Vieira Freitas dos Santos ${ }^{1}$, Leilane Barbosa de Sousa ${ }^{1}$

Objective: to describe the perceptions of women assisted in the Family Health Strategy about embracement in gynecological nursing consultations. Methods: qualitative study conducted semi-structured interviews with 24 women. The data were analyzed through thematic content analysis. Results: the discourses revealed the women's understanding about embracement as the way they are treated by the nurses during the gynecological consultation and the establishment of bond and trust. Women also exposed the positive influence of embracement in health promotion and prevention of cancer of the uterine cervix. Conclusion: embracement of women in gynecological nursing consultations was perceived as an indispensable action for comprehensive health care because it promotes positive results for adherence to uterine cervical cancer prevention strategies.

Descriptors: User Embracement; Humanization of Assistance; Uterine Cervical Neoplasms; Women's Health.

Objetivo: descrever as percepções de mulheres atendidas na Estratégia Saúde da Família acerca do acolhimento nas consultas ginecológicas de enfermagem. Métodos: estudo qualitativo, realizado por meio de entrevista semiestruturada com 24 mulheres. A análise dos dados ocorreu mediante análise de conteúdo temática. Resultados: os discursos revelaram a compreensão das mulheres sobre o acolhimento como a forma como são tratadas pelos enfermeiros durante a consulta ginecológica e no estabelecimento de vínculo e confiança. As mulheres também expuseram a influência positiva do acolhimento na promoção da saúde e prevenção do câncer de cervicouterino. Conclusão: o acolhimento das mulheres na consulta ginecológica de enfermagem foi percebido como uma ação indispensável para o cuidado integral à saúde, visto que promove resultados positivos para a adesão às ações de prevenção do câncer cervicouterino.

Descritores: Acolhimento; Humanização da Assistência; Neoplasias do Colo do Útero; Saúde da Mulher.

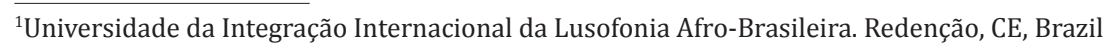

Corresponding author: Maria Gleiciane Lima Rocha

Rua Stael Gomes Bezerra, 479, CEP: 62.750-000, Aracoiaba, CE, Brazil. E-mail: mariagleicirocha1992@hotmail.com.br 


\section{Introduction}

Embracement is one of the guidelines of the National Humanization Policy created in 2003, considered a relational technology that has contributed to the effectiveness of bonding and knowledge about the true health needs of the population. The National Humanization Policy, also called HumanizaSUS, seeks the participation of actors involved in the health environment, such as health managers, workers and users ${ }^{(1)}$.

Another important point of the National Humanization Policy is the principle of transversality, which must permeate all the policies and programs of the Unified Health System, through communication, constructive interaction between specialties, practices, professionals and users of the services ${ }^{(1)}$.

In the context of women's health, cervical cancer represents a serious global problem, especially in developing countries where the conditions for access to early detection and treatment are more difficult. Recent data show that 270,000 women die each year from uterine cervix cancer in low- and middle-income countries, and that this is the second most common cancer in the world ${ }^{(2)}$.

Uterine cervical cancer rates are considered high In Brazil, and 16,370 new cases were estimated for the 2018-2019 biennium ${ }^{(3)}$. Screening for cancer of the uterine cervix in Primary Health Care, in the Family Health Strategy, through the accomplishment of the cytopathological examinations, in women within the recommended age group of 25 to 64 years, with a periodicity in accordance to the guidelines of the Ministry of Health, may lead to a reduction in the incidence and mortality rates of the neoplasia in question ${ }^{(4)}$.

It is also noted that frequent Human Papillomavirus infections by specific types (16 and 18) cause precursor lesions of uterine cervix cancer which, if left untreated, can become cancer ${ }^{(4)}$.

In the pre-clinical phase of uterine cervix cancer there are no symptoms, and precursor lesions can be detected by gynecological preventive examination and treated in a timely manner. Such examination may increase the chance of cure in some cases up to $100.0 \%$. It is evident that uterine cervix cancer has a slow evolution, but when not diagnosed in the initial phase, the disease evolves and symptoms such as vaginal bleeding, discharge and pain appear ${ }^{(5)}$.

Evidence shows that there has been a reduction in mortality rates from breast and uterine cervix cancer with the intensification of screening tests in Brazil. However, in the North and Northeast regions, there was an increase in mortality from uterine cervix cancer in people who live below the poverty line in the period evaluated by the study from 1980 to $2010^{(6)}$.

The practice of embracement by health professionals, based on dialogue and effective communication, has the potential to facilitate the process of humanization, to stimulate women's adherence to cytopathological examination through the exchange of knowledge about the purpose of this examination and reduction of knowledge deficit ${ }^{(7)}$.

Nurses play an important role in the context of women's health in the Family Health Strategy. They have the technical and theoretical competence to perform gynecological nursing consultations and cytopathological examinations ${ }^{(4)}$.

Thus, it is not enough to know the view of health professionals about the care offered, but it is also necessary to know how those who receive the care perceive it, aiming at improvements. It is necessary to give voice to the health service users and to have a feedback on the use of light health technologies ${ }^{(1)}$. Thus, the question that guided this study was: what is the perception of women assisted in the Family Health Strategy about embracement in gynecological nursing consultations and its contribution to the prevention of uterine cervix cancer?

Based on the context presented, this study aimed to describe the perceptions of women assisted in the family health strategy about embracement in gynecological nursing consultations. 


\section{Methods}

Qualitative research carried out with women assisted in the Family Health Strategy in the municipalities of Aracoiaba and Redenção, Maciço de Baturité-CE, Brazil.

Qualitative research in the health area allows understanding various aspects that involve health actors, be they professionals, managers or users, as well as aspects about the functioning and quality of $\operatorname{care}^{(8)}$. Twenty-four women aged 20 to 59 years who met the following inclusion criteria participated in the study: having performed cytopathological examination or Papanicolaou test at least once in their lives and being aged 18 years or more. Data collection took place in the period from March to August of 2016, in four Basic Health Units, according to the schedule of consultations of the professional nurses for gynecological prevention care.

Women in the health service were approached through verbal invitation and presentation of the Informed Consent Form, in printed form, containing all the information about the objectives and other clarifications of the study, including the ethical aspects. The code USER followed by a number indicating the order of the interview was used in order to maintain anonymity in the speeches. The semi-structured interviews with open questions were carried out individually, randomly, in a reserved place. Each interview lasted 25 minutes on average.

The questions contained in the script were the following: Age; Marital status; Schooling; Occupation; Income; Define what is embracement; How do nurses receive you in the consultation? Give your opinion; Do you clarify your doubts with these professionals?; Are your questions clarified?; Do you consider that embracement influences health promotion, prevention and fight against uterine cervix cancer? Give your opinion; How does embracement influence your return to the unit to carry out new procedures or continuity of care? Give your opinion; How long have you been treated by the same health professional? Do you know the name of the professional that receives you?

At the beginning of the interviews, the women were informed about the request to have their speeches recorded; however, most of them did not give their consent to the recording and we respected the rights of these participants. The record of the answers and the interviewer's impressions were written in a field notebook. Then the data was entered into an Excel 2010 spreadsheet for organization and analysis.

During data collection, when the sixth question of the interview script was asked, it was observed that most of the participants did not know the meaning of embracement, and there was therefore a need for contextualizing the term. This action was necessary to provide women with the contextualization of embracement in the health care context.

The final number of interviews was defined according to theoretical saturation, a technique frequently used in qualitative research, since the intention of this criterion is the search for understanding the facts and not to reach a given the number of people invol$\operatorname{ved}^{(9)}$.

Interviews were organized and analyzed using the Thematic Content Analysis Technique, which consists of three steps: pre-analysis (systematization of initial ideas, using repeated and exhaustive reading in order to have a closer familiarization with the material); exploitation of the material (codification of the material by pre-defined rules); and data interpretation $^{(10)}$. The identified categories were discussed based on existing literature on the subject.

The Informed Consent Term was presented to all the participants of this research, specifying the voluntary nature of the study and the possibility of withdrawal at any time, as well as other norms. The study was approved by the Research Ethics Committee of the Universidade da Integração Internacional da Lusofonia Afro-Brasileira, under the opinion $\mathrm{n}^{-}$ 1.437.703/2016. 


\section{Results}

Women who participated in the study were aged between 20 and 59 years and reported being married (58.3\%), unmarried (33.3\%) and widowed (8.3\%). As for schooling, they had complete Higher Education (12.5\%), Incomplete Higher Education (8.3\%), Complete High School (25.0\%), Incomplete High School (8.3\%), Complete Elementary Education $(25 \%)$ and Incomplete Elementary Education $(20.8 \%)$. When asked about income, the majority $(62.5 \%)$ did not report the amount received. Those who reported income, $25.0 \%$ received one minimum wage, $4.1 \%$ received two minimum wages, $4.1 \%$ had income above one minimum wage and $4.1 \%$ had an income of less than one minimum wage.

After the organization and analysis of the speeches, five categories emerged: Women's perceptions about the term embracement; Embracement at gynecological nursing consultations to prevent uterine cervix cancer; Embracement in the nursing consultations and its influence in health promotion and prevention of uterine cervix cancer; Resolutivity of the consultation for the women's health needs; and Embracement and continuity of care.

\section{Women's perceptions about the term embrace- ment}

When asked about the meaning of the term embracement, the women ascribed the meaning of reception offered in a given place, reception kind of reception that provides well-being and satisfaction. They also related the meaning of embracement to the way they are treated in the Health Units at the entrance of the service. This is evidenced in the speeches: Embracement begins at the start, from the moment you arrive at the Health Unit, from since reception until the moment of the consultation. It is consistency during the service, the way you are treated (USER-02). It is, for example: the reception, the person tells you good morning, clarifies your doubts or seeks someone who can answer your questions (USER-03). Embracement for me is to be welcomed, is to be in a warm environment and feel good. It is very annoying to arrive in an environment and be unwelcome; but not here, we are well received (USER-11). I've never heard about embracement (USER-21).

\section{Embracement at gynecological nursing consulta- tions to prevent uterine cervix cancer}

In this category, the women related embracement in gynecological nursing consultations to the way they are received in the physician's office by nurses. In their speeches, the presence of dialogue, clarification of doubts, information on the procedures to be performed, as well as the evaluation of test results and other necessary conducts in each case were highlighted. They consider that these professionals provide embracement when the communication and resolutivity are present, as can be observed in the speeches: They ask questions about your health state, if you smoke, then they give advice, prescribe medicines when necessary (USER- 01). Whenever I come, she (the nurse) welcomes me (USER-08). She (the nurse) receives us, asks us how we are and what we are feeling (USER-10). She (the nurse) welcomes us well, talks to us, encourages us to speak, clarifies our questions, she does not hold back anything about our health and about the results of the tests (USER-11). The professional fill out a form, she asks questions and provides guidance on the procedure (USER-23).

\section{Embracement in the nursing consultations and its influence in health promotion and prevention of uterine cervix cancer}

Women in the study expressed their perceptions about the relationship between embracement during the nursing consultation and health promotion and prevention of uterine cervix cancer.

It was observed that the participants of the study considered that the way they are received by the health professional during the nursing consultation for the prevention of cervix cancer has a positive influence on health promotion and prevention of this neoplasia. Aspects related to health education and to the stimulus to change life habits were observed in their speeches. Here are the lines: She (the nurse) gives us counsel, tells us how the treatment should be done (USER-01). It 
does influence health promotion, because you can ask questions about various topics (USER-07). It influences health promotion because we started to encourage other women to make the test. There are women who spend years without making the test or never did in life, out of fear (USER-11). Because I will know and I will do the prevention, she (the nurse) always gives lectures on cancer prevention (USER-12). It promotes health because I try to follow what she (the nurse) suggests (USER-13).

\section{Resolutivity of the consultation for the women's health needs}

The women stated that the service offered to women's health has partial resolutivity. Among the reports, problems related to the lack of materials to perform procedures (cytological examination), reception in the health units, lack of medication, reports contrary to resolutivity and provision of adequate listening, and non-accomplishment of adequate embracement by professionals in the Health Units, were mentioned: It is resolutive, although some materials are lacking, which is not the professionals' fault (USER-01). It is resolutive. It could improve on the issue of material, which is sometimes lacking, but, it is not the fault of the professional who is making the consultation (USER-22). Yes, it is resolutive, in part, because there are barriers in the consultation. The reception of the unit should improve, and the scheduling of further tests should delay less, as well as the lack of medicines. Communicating and passing on information to the population needs to improve as well (USER-23).

\section{Embracement and continuity of care}

The women's speeches revealed that embracement has an influence on their return to the Basic Health Unit. These speeches include the importance of returning to the Basic Health Units to collect the results of the cytopathological test and take them to be analyzed by nurses, as well as returning to the health units to receive further care from the same professional. In their speeches, they consider that the way the nurses establish the dialogue and their conduct during the service collaborate to this return: Depending on the way you are assisted, you want to return (USER-02). I always come back to be seen by this professional (USER-04). Yes, I return and I want to know the result, because it is not enough to just make the examination (USER-11). To receive the result and give it to the nurse (USER-12).

\section{Discussion}

The present article had as limitation the refusal of the women to have their speeches recorded. This fact may have caused a loss of information during the notes. The results of this study are significant because they show the importance of the use of light technologies by health professionals during provision of care and their potential to stimulate the adherence of health service users to healthier health practices such as preventive examination of uterine cervical cancer. The reports showed that the women perceive embracement as the presence of cordiality in the attendance, in the approach of the professionals in the Health Units, the fact of having their doubts clarified, an environment favorable to the listening and resolution of the complaints throughout their experience within the health service. As evidenced in other studies on the understanding of women of embracement in health services, the predominance of good embracement, good treatment for users by professionals and access to services in the Basic Health Units predominated ${ }^{(11)}$.

In the field of health, embracement is a frequently used concept because it is also a light technology related to communication. Embracement is also one of the guidelines of the National Humanization Policy. This Health Policy seeks to consolidate the principles of the Unified Health System in health services, based on changes and the association between management and care practices ${ }^{(1)}$.

It is important to understand the meanings of bonding in health services because since it is believed that comprehensive care can be achieved through it, where users can have more autonomy to make decisions and participate in the management of their own health $^{(12)}$.

However, the most emphasized dimension in the women's speeches was embracement-dialogue. 
In the literature, embracement can be divided into three dimensions: embracement of dialogue, attitude and reorganization of health services. In the dimension of dialogue, embracement integrates different people, connects several areas of care and increases the opportunities of movements through the system. It works as an element that connects people to the system. Furthermore, communication is indicated as an element of health services. Yet, embracement-dialogue also assumes concerns and management of hostilities $^{(11)}$.

Embracement is also a moment of meeting, listening. It favors the establishment of a link between users and health professionals ${ }^{(1)}$. In this environment of meeting, nurses should promote health education so that women be clarified about the purpose of the examination, and have awareness of the value of this test and return to continue care ${ }^{(13)}$, because the lack of knowledge about the Pap smear test is one of the barriers to its non-realization ${ }^{(14)}$.

In the present study, women reported the positive influence of embracement on health promotion. They also endorse the importance of the guidelines offered during nursing consultations to prevent uterine cervix cancer, characterizing an individual educational approach ${ }^{(12)}$. Therefore, nursing consultations should be a space for women to express their questions, a space for open dialogue and where all aspects of the individuals are considered ${ }^{(15)}$.

Women should be guided by qualified health professionals regarding factors that may influence the appearance of precursor lesions of uterine cervix cancer such as Human Papillomavirus infection. They must also receive information on the forms of prevention, through the use of female or male condoms. It is important to focus on the vaccines available to adolescents, in the age groups recommended by the Ministry of Health, noting that women who seek care mostly play the role of mothers, caregivers, and even heads of families ${ }^{(4)}$.

Therefore, the actions performed by health professionals during consultations can be favorable and can stimulate the adherence of women to treatment and their search for services offered in the Health Units. In the health care of the female population, comprehensive care can be strengthened with attitudes such as respect and solidarity, and, as a consequence, through the creation of bond and trust ${ }^{(16)}$.

In the context of uterine cervix cancer prevention, in order to strengthen and expand the coverage of screening, several multidisciplinary actions are necessary, and among them is qualified listening of the users' complaints, health education, promotion of bonding and integrality of care ${ }^{(4)}$.

They also include actions that aim at directing care to health service users through multidisciplinary and interdisciplinary work with Community Health Agents, in the activity of active search, in the promotion of bond with users, and in the organization and scheduling of consultations per coverage area. In this sense, it is necessary to reflect on the humanistic skills that health professionals must develop in order to establish a relationship of trust and bond with women. These humanistic skills are empathy, subjectivity, and availability $^{(11)}$.

\section{Conclusion}

Embracement of women in gynecological nursing consultations was perceived as an indispensable action for comprehensive health care because it promotes positive results in terms of adherence to uterine cervix cancer prevention actions.

\section{Collaborations}

Rocha MGL and Linard AG participated in designing the project, analyzing the data, writing the article and approving the final version to be published. Santos LVF and Sousa LB contributed to the writing, critical analysis of the intellectual content of the article and approval of the final version to be published. 


\section{References}

1. Ministério da Saúde (BR). Política Nacional de Humanização [Internet]. 2015 [citado 2018 jan 08]. Disponível em: http://bvsms.saude.gov.br/bvs/ folder/politica_nacional_humanizacao_pnh_1ed. pdf

2. World Health Organization (WHO). Guidance note: comprehensive cervical cancer prevention and control: a healthier future for girls and women [Internet]. 2013 [cited 2018 Jan. 12]. Available from: http://apps.who.int/iris/bitstre am/10665/78128/3/9789241505147_eng.pdf?ua $=1$

3. Ministério da Saúde (BR). Instituto Nacional do Câncer. Estimativa 2018: Incidência de Câncer no Brasil [Internet]. 2018 [citado 2018 jun. 05]. Disponível em: http://www.inca.gov.br/ estimativa/2018/estimativa-2018.pdf

4. Ministério da Saúde (BR). Controle dos cânceres do colo do útero e da mama [Internet]. 2013 [citado 2018 jan. 12]. Disponível em: http:// bvsms.saude.gov.br/bvs/publicacoes/controle_ canceres_colo_utero_2013.pdf

5. Ministério da Saúde (BR). Instituto Nacional do Câncer. Colo do útero: detecção precoce [Internet]. 2016 [citado 2018 jun. 05]. Disponível em: http://www2.inca.gov.br/wps/wcm/connect/ tiposdecancer/site/home/colo_utero/deteccao_ precoce

6. Girianelli VR, Gamarra CJ, Silva GA. Disparities in cervical and breast cancer mortality in Brazil. Rev Saúde Pública 2014; 48(3):459-67. doi: http://dx. doi.org/10.1590/S0034-8910.2014048005214

7. Andrade SSC, Silva FMC, Silva MSS, Oliveira SHS, Leite KNS, Sousa MJ. Compreensão de usuárias de uma unidade de saúde da família sobre o exame Papanicolau. Ciênc Saúde Coletiva. 2013; 18(8):2301-10. doi: http://dx.doi.org/10.1590/ S1413-81232013000800014

8. Minayo MCS, Guerriero ICZ. Reflexividade como éthos da pesquisa qualitativa. Ciênc Saúde Coletiva. 2014; 19(4):1103-12. doi: http://dx.doi. org/10.1590/1413-81232014194.18912013
9. Minayo MCS. Amostragem e saturação em pesquisa qualitativa: consensos e controvérsias. Rev Pesq Qual [Internet]. 2017 [citado 2018 jan. 12]; 5(7):1-12. Disponível em: https://editora. sepq.org.br/index.php/rpq/article/view/82/59

10. Bardin L. Análise de conteúdo. Lisboa: Edições 70; 2011.

11. Guerrero P, Mello ALSF, Andrade SR, Erdmann AL. User embracement as a good practice in primary health care. Texto Contexto Enferm. 2013; 22(1):132-40. doi: http://dx.doi.org/10.1590/ S0104-07072013000100016

12. Garuzi M, Achitti MCO, Sato CA, Rocha SA, Spagnuolo RS. Acolhimento na Estratégia Saúde da Família: revisão integrativa. Rev Panam Salud Pública [Internet]. 2014 [citado 2018 jan. 17]; 35(2):144-9. Disponível em: https://www. scielosp.org/pdf/rpsp/2014.v35n2/144-149/pt

13. Silva MM, Gitsos J, Santos NLP. Atenção básica em saúde: prevenção do câncer de colo do útero na consulta de enfermagem. Rev Enferm UERJ [Internet]. 2013 [citado 2018 jun. 05]. 21(esp.1):631-6. Disponível em: http://www.epublicacoes.uerj.br/index.php/enfermagemuerj/ article/view/10039/7825

14. Lima ANF, Nascimento EGC, Alchieri JC. Adesão ao exame de citologia oncótica: um olhar sobre a saúde da mulher. Rev APS [Internet]. 2014 [citado 2018 jan. 17];17(3):303-10. Disponível em: https://aps.ufjf.emnuvens.com.br/aps/article/ view/1943/821

15. Michelin SR, Marchi JG, Hyeda IS, Heidemann ITSB, Nitschke RG. Percepção das mulheres sobre promoção da saúde durante a consulta de enfermagem. Ciênc Cuid Saúde. 2015; 14(1):901-9. doi: http://dx.doi.org/10.4025/cienccuidsaude. v14i1.20300

16. Ressel LB, Stumm KE, Rodrigues AP, Santos CC, Junges CF. Exame preventivo do câncer de colo uterino: a percepção das mulheres. Av Enferm [Internet]. 2013 [citado 2018 jan. 12];31(2):65-73. Disponível em: http:// www.scielo.org.co/scielo.php?script $=$ sci arttext\&pid=S0121-45002013000200007 